\title{
PrEP in India's HIV Prevention Policy in the Era of Social Media and Sex Positivity
}

\section{Anindya Kar ${ }^{1 *}$, Dinesh Bhugra², Shuvankar Mukherjee ${ }^{3}$, Agnibho Mondal $^{4}$, Aaditya Suresh Kumar ${ }^{5}$}

\author{
${ }^{1}$ Department of Psychiatry, Advanced \\ Neuropsychiatry Institute, Kolkata, India; \\ ${ }^{2}$ Health Service and Population Research \\ Department, Institute of Psychiatry, \\ Psychology \& Neuroscience, King's College \\ London, London, UK; \\ ${ }^{3}$ Department of Community Medicine, \\ Calcutta National Medical College, Kolkata, \\ India; \\ ${ }^{4}$ Department of Tropical Medicine, School of \\ Tropical Medicine, Kolkata, India; \\ ${ }^{5}$ Department of Neurology, Institute of \\ Neurosciences, Kolkata, India \\ *Corresponding Author
}

\section{(cc) EY}

New articles in this journal are licensed under a Creative Commons Attribution 4.0 United States License.

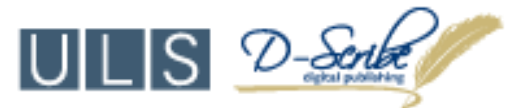

This journal is published by the University Library System of the University of Pittsburgh as part of its D-Scribe Digital Publishing Program and is cosponsored by the University of Pittsburgh Press. 


\section{Abstract}

Introduction: The global revolution of online social media and connectivity had a tremendous effect on sexual behavior in both developed and developing countries. This global change is influencing the societal structure and existing social principles. Moreover, it has a significant impact on the epidemiology of different infectious diseases, especially HIV.

Discussion: India is one of the most diverse democratic countries that has undergone a social-cultural transition in the last decade. However, having the second-highest HIV infection rate in the world, India does not have any other new prevention tools in their national HIV prevention strategy. Pre-Exposure Prophylaxis (PrEP), a boon of HIV prevention widely used in different countries, is still not implemented in India. The concept of "Digital India" by the Government of India is giving wide access of internet to the people of India. Furthermore, people are exposed to social media, and that is impacting their sex seeking behavior. Interestingly, recent legal changes in India promotes sex positivity. It also calls for introspection on existing HIV preventive strategies. Conclusion: Given the current scenario of PrEP and other existing preventive measurements of HIV, further research is needed to determine the acceptance and efficacy of PrEP and improve engagement in care for individuals in India. Various international studies recommend effective implication of PrEP to reduce the rate and economic burden of HIV infection.

Keywords: HIV; PrEP; Social Media; India; Sex Positivity

\section{PrEP in India's HIV Prevention Policy in the Era of Social Media and Sex Positivity}

\section{Anindya $\mathrm{Kar}^{1}$, Dinesh Bhugra², Shuvankar Mukherjee ${ }^{3}$, Agnibho Mondal $^{4}$, Aaditya Suresh Kumar ${ }^{5}$}

\author{
${ }^{1}$ Department of Psychiatry, Advanced \\ Neuropsychiatry Institute, Kolkata, India; \\ ${ }^{2}$ Health Service and Population Research \\ Department, Institute of Psychiatry, Psychology \& \\ Neuroscience, King's College London, London, \\ UK; \\ ${ }^{3}$ Department of Community Medicine, Calcutta \\ National Medical College, Kolkata, India; \\ ${ }^{4}$ Department of Tropical Medicine, School of \\ Tropical Medicine, Kolkata, India; \\ ${ }^{5}$ Department of Neurology, Institute of \\ Neurosciences, Kolkata, India
}

\section{Research}

India's socio-cultural transition in the last decade has been impactful on the demography of HIV ${ }^{1}$. The recent explosion in social media usage and the Digital India campaign are remarkably changing human interaction on many levels. The giants of social media like Facebook and Twitter, along with dating apps like Tinder and Grindr, are not restricted to a particular group of people in India but cater to wide and diverse populations. This heterogeneous distribution of social media users has an impact on sexual behavior and its risks. Furthermore, it appears that the incidence and prevalence of HIV varies among people of different cultural backgrounds due to an interplay of psychological and social factors. The provision of healthcare in any democratic country, such as India, is influenced by the demands of its people of many different cultural identities and relies on social, political and economic factors to achieve an optimal prevention policy. The recent changes in HIV prevention policy of India where every individual with HIV positive status are being treated with free antiretroviral therapy (ART)

This work is licensed under a Creative Commons Attribution 4.0 United States License.

This journal is published by the University Library System of the University of Pittsburgh as part of its D-Scribe Digital Publishing Program and is cosponsored by the University of Pittsburgh Press. 
irrespective of their CD4 count are definitely ${ }^{1}$ benefitting the people living with HIV (PLHIV). However, HIV infection is a significant public health burden in India, and Pre-Exposure Prophylaxis (PrEP) is still an alien concept. The global sexual renaissance ${ }^{2}$ has changed societal attitude towards consensual online sex. In India, online dating applications and websites are also widely used, and the pattern of sex-seeking behavior has drastically changed in the last few years ${ }^{3}$. Policy makers need to take into consideration behavioral responses to changes in the cost of disease and implement strategies that are holistic and long-sighted. This paper will review these changes and how they impinge upon and, by so doing, help the policy makers and clinicians to identify the need of PrEP and address these issues in a culturally sensitive way.

\section{Discussion}

\section{Global perspective of $\operatorname{PrEP}$}

Behavioral interventions and barrier methods, such as the use of condoms, slowed down the HIV epidemic in past ${ }^{4}$, but as long as no vaccine is available, new intervention strategies are still urgently needed. The two drug fixed-dose combination therapy with emtricitabine/tenofovir disoproxil fumarate (FTC/TDF) became the first to be used as PrEP, known as Truvada, and was approved by USA Food and Drug Administration (FDA) in July 2012 for high risk groups ${ }^{5}$. Both TDF and FTC are nucleos(t)ide analogue reverse transcriptase inhibitors (NRTIs). They have longer halflives, which allow for less frequent dosing ${ }^{6}$. In fact, the half-lives of TDF/FTC are the longest for the NRTI class, a potentially favorable pharmacological characteristic for PrEP from an adherence perspective $e^{3}$. Prior to the FDA licensure there was a series of meta-analyses of studies on PrEP that had been done on high risk groups, i.e. those who are vulnerable to HIV infections. A sub-analysis of the men who have sex with men (MSM) study (known as the Pre-Exposure Prophylaxis Initiative [iPrEX]) showed that with optimal adherence, efficacy was more than $90 \%$, and incidence of HIV infection was reduced by $92 \%^{7,8}$. Other trials, including one among serodiscordant heterosexual couples in Kenya and Uganda and another among sexually active young men and women in Botswana, have also demonstrated promising results for the use ${ }^{9}$ of PrEP as a prevention strategy. As clinical trials continue to establish efficacy, researchers have been increasingly interested in awareness and acceptability among potential candidates of PrEP. Studies have found that overall knowledge of PrEP is low to modest, with concerns relating to potential side effects, costs, drug resistance and accessibility ${ }^{10}$. On a recent study amongst HIV-negative individuals, some men suggested that the reason for the likely future adoption of PrEP was the opportunity to engage in sex without condom use, either with their serodiscordant partner or casual partners. Other participants equated PrEP adoption with greater sexual freedom ${ }^{11}$.

In July 2014, the World Health Organization (WHO) suggested that all MSM should consider taking PrEP in conjunction with other risk reduction strategies ${ }^{12}$. Countries like South Africa, Australia, United Kingdom, Germany and other European countries have considered PrEP as an emerging strategy and an important addition to the toolbox of HIV prevention ${ }^{13}$. Understanding the cultural context of PrEP provision is vital for implementation, with factors such as sexual practice, age and gender playing important roles in HIV acquisition risk and acceptability of interventions. Pressure has increased globally for countries to submit to regulatory authorities and include PrEP in national policies.

\section{HIV in India-Current scenario and challenges}

The most prevalent mode of HIV transmission in India is sexual route ${ }^{14}$. According to the recent data of 2018, the new HIV infections increased to 88,000 from 80,000 and AIDS-related new deaths increased to 69,000 from 62,000 in India ${ }^{15}$. The UNAIDS data suggests almost $79 \%$ of PLHIV are aware of their status and on effective ART. The treatment efforts, primarily through

This work is licensed under a Creative Commons Attribution 4.0 United States License.

This journal is published by the University Library System of the University of Pittsburgh as part of its D-Scribe Digital Publishing Program and is cosponsored by the University of Pittsburgh Press.

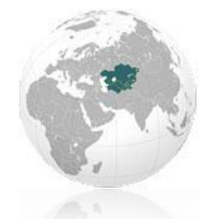




\begin{tabular}{lc}
\hline Region & Adult HIV Prevalence (\%) \\
\hline India & $\mathbf{0 . 2 2}$ \\
Mizoram & 2.04 \\
Manipur & 1.43 \\
Nagaland & 1.15 \\
Telangana & 0.7 \\
Andhra Pradesh & 0.63 \\
Karnataka & 0.47 \\
Goa & 0.42 \\
Maharashtra & 0.33 \\
Delhi & 0.3 \\
Tamil Nadu & 0.22 \\
\hline
\end{tabular}

Table 1. States with Adult (15-49 years) HIV Prevalence about the National Average, 2017

ART, helped to manage their infection. Most importantly, the introduction of Indian government's 'test-and-treat' policy, irrespective of the CD4 counts and clinical stage of the disease, catalyzed the process of "Treatment as Prevention" (TasP) ${ }^{11}$ Moreover, the rate of new infections and deaths is not falling rapidly enough in meeting the 90-90-90 ambitious treatment target to help end the AIDS epidemic given by the Joint United Nations Programme on HIV/AIDS (UNAIDS) ${ }^{16}$. The state wise prevalence of HIV infections in India given by National AIDS Control Organization (NACO) in 2017 is elaborated in Table 1 and Figure 1. A recent study says PrEP with a biannual testing program has the potential to improve average per-person survival by nearly one year and block more than 270,000 HIV transmissions in India $^{17}$. PrEP drug costs ${ }^{18}$ are lower than HIV treatment costs, both per-dose and for the duration of use. Moreover, PrEP is prescribed to be taken consistently, but only when someone is at heightened risk of HIV, whereas, should someone acquire HIV, they will need to be on ART for their entire life in order to stay healthy ${ }^{18,19}$. In May 2018, drug maker Cipla received regulatory approval in India to sell its version of Truvada as Tenvir $\mathrm{EM}^{20}$. However, this highly expensive monthly drug remains out of reach for many people who want and need it. There are no studies from India that can establish the efficacy or acceptance of PrEP in India. The only trial that has ever been done on PrEP in India focused on female sex workers, led by The Sonagachi Project in Kolkata $^{15}$. The trial was designed to assess PrEP feasibility in that particular population but did not provide sufficient evidence to recommend that PrEP be made routinely available by the National or State AIDS Control Programs for high risk individuals.

Social media and the change in sex-seeking behavior

With the development of the Internet and mobile technology, the ways of socializing and seeking sexual partners have changed dramatically ${ }^{21}$. Mobile online dating applications like Grindr and Tinder along with other social media sites are widely used to seek potential sexual partners among both heterosexual and homosexual people ${ }^{22}$. Seal et al. suggest that because the Internet can accommodate a variety of sexual

This work is licensed under a Creative Commons Attribution 4.0 United States License.

This journal is published by the University Library System of the University of Pittsburgh as part of its D-Scribe Digital Publishing Program and is cosponsored by the University of Pittsburgh Press. 
expressions, as well as allow anonymity for the user, it provides an ideal environment to explore sexuality ${ }^{23}$. Online partner seeking also allows people to more precisely delineate specific partner characteristics, such as HIV serostatus or a desire to engage in certain types of sexual behaviours ${ }^{20}$. However, there is no literature on sex-seeking behavior in India, especially on the use of social media. Most of the current literature on the use of the social media has focused on MSM. In contrast, relatively little research, especially qualitative research, has focused on heterosexual individuals. This is potentially due to the large burden that HIV infection has on MSM populations or that MSM use the Internet more actively to find sex than heterosexual men and women ${ }^{24}$. It was estimated that in the beginning of 2018, there were almost 3 million users on one of the most popular heterosexual dating apps in India ${ }^{25}$. On the other hand, various gay dating apps also have a significant number of users, one example being Grindr, which boasts around 4.5 million users worldwide as of $2020^{26}$. Gay dating apps often give reminders of HIV testing, ask if the person is on PrEP and whether the person has an undetectable viral load if the person is seropositive ${ }^{27}$. These dating apps also spread the message that "undetectable equals untransmittable" ${ }^{28}$. Undetectable equals untransmittable is the message of the UNAIDS campaign that shows the evidence demonstrating that HIV treatment is highly effective in reducing the transmission of HIV ${ }^{29,30}$.

Apart from this, Facebook is also used for no strings attached sexual encounters ${ }^{31}$. Another popular application, Instagram, is also quite popular among the youth to find casual partners for physical intimacy ${ }^{32}$. There were around 201 million and 35 million Indian users on Facebook and Instagram respectively in $2017^{33}$.

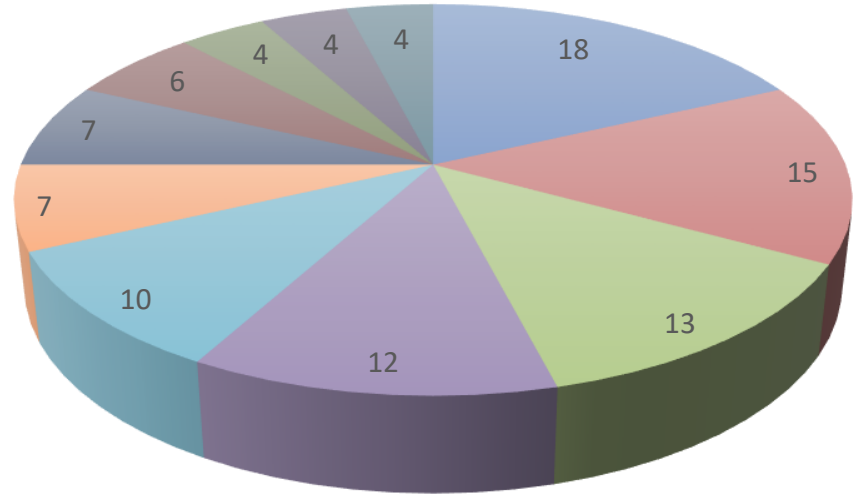

$\begin{array}{ll}\square \text { Remaining States/UT } & \square \text { Maharashtra } \\ \square \text { Telangana } & \text { Tamil Nadu } \\ \square \text { Bihar } & \square \text { Gujarat }\end{array}$

$\square$ Andhra Pradesh $\quad \square$ Karnataka
$\square$ West Bengal
$\square$ Uttar Pradesh
$\square$ Rajasthan

Source: National AIDS Control Organization of India, 2017

Figure 1. People Living with HIV, Percent Distribution Among States, 2017

This work is licensed under a Creative Commons Attribution 4.0 United States License.

This journal is published by the University Library System of the University of Pittsburgh as part of its D-Scribe Digital Publishing Program and is cosponsored by the University of Pittsburgh Press. 
Sex positivity and legal changes

Sex positivity is defined as "a positive attitude to sexual activity that is seen as a healthy relationship and form of self-expression" ${ }^{34}$. Sexual pleasure is a valuable attribute in itself even without the context of marriage, procreation or an intimate relationship. It is, in itself, an important and positive part of human existence. "Hookups" or uncommitted sexual encounters, are becoming progressively more engrained in popular culture, reflecting both evolved sexual predilections and changing social and sexual scripts ${ }^{35}$. This particular trend has been catalyzed by emerging online dating apps coming into the mainstream and challenged the existing ideas of monogamous relationships, prioritizing consensual $\mathrm{sex}^{36}$.

Social change influences laws ${ }^{37,38}$. In 2014, the Supreme Court of India recognized the transgender persons as members of a third gender alongside male and female $^{39}$. In January of 2018, the Supreme Court in its judgment on privacy, said that Right to Privacy and the protection of sexual orientation lie at the core of the fundamental rights guaranteed by Articles 14, 15 and 21 of the Indian Constitution ${ }^{40}$. On September 06, 2018, in a historic judgment, the Supreme Court of India removed consensual adult sex as a crime under section 377 , saying sexual orientation is natural and people have no control over $\mathrm{it}^{41}$. Before this, the law particularly affected the Lesbian, Gay, Bisexual, Transgender (LGBT) community and violated the right to form association under Article 19 of the Indian Constitution ${ }^{42}$. On September 27, 2018, the apex court also ruled that adultery is no longer a crime under law, recognizing that the colonial-era law was unconstitutional and had some gender based discriminatory elements ${ }^{43}$.

\section{Empowering with PrEP}

PrEP empowers the susceptible people including women to HIV infection ${ }^{44}$. PrEP also reduces the stigma of HIV infection and hence acts as an emancipator of people living with HIV by reducing the risk of acquiring HIV infection amongst serodiscordant couples $^{39}$. PrEP is considered as an option for HIVnegative women who want to have a baby with their partner living with $\mathrm{HIV}^{45}$. It is also considered as a mature and empowering approach for a person who is in a relationship with a partner who is not willing to use preventive measures. Furthermore, it is a valuable method that allows women to protect themselves from HIV infection without dependence on their male sex partners to use condoms.

On the other hand, there is a wide range of stigma and stereotyping regarding certain sexual positions within the gay community ${ }^{46}$. The bottom, or receptive partner during sexual intercourse, is 13 times more likely to get infected with HIV than the top, who is the insertive partner ${ }^{47}$. Furthermore, bottom shaming is highly prevalent due to the gender roles related stigma, as the receptive partner is associated with femininity ${ }^{48}$. PrEP is the first opportunity bottoms have ever had to be in full control of their risk of HIV transmission. Moreover, it allows both partners, regardless of sexual position, to be responsible for their own protection ${ }^{49}$. In a country like India, where almost $90 \%{ }^{50}$ of transgender people are involved in sex work, PrEP, if implemented, will be added to the arsenal of measures they can employ to protect themselves ${ }^{51}$.

\section{Recommendations}

Implementation of PrEP is a long time constructive work. A few recommendations that can be considered are

a)Policy makers should be sensitive to cultural backgrounds and aware of social changes.

b) There should be further studies on acceptance, efficacy and side effects of PrEP in India.

c)The medical curriculum needs to be gender sensitive and it is important to discourage moral

This work is licensed under a Creative Commons Attribution 4.0 United States License.

This journal is published by the University Library System of the University of Pittsburgh as part of its D-Scribe Digital Publishing Program and is cosponsored by the University of Pittsburgh Press. 
judgement in clinical practices. The new updates of HIV medicine like effectiveness of ART to reduce transmissibility, usefulness of PrEP, etc. should be taught to the primary health care physicians.

d)The first step in implementing PrEP is identifying persons at high risk of HIV acquisition. However, identifying such persons can be challenging due to perceived fear of stigma and social discrimination. The lack of a trusting relationship between the patient and the clinician may also make it harder. Hence it is important that clinicians routinely take a sexual and injection drug use history for all their patients in an open and nonjudgmental manner.

PrEP is only fully effective when it is adhered to exactly as prescribed. Furthermore, it does not protect against other sexually transmitted infections (STIs). Hence, it needs to be delivered as part of a comprehensive package of HIV/STI prevention services based on an individual's circumstances.

\section{References}

1. Jayanta Bhattacharya. HIV prevention \& treatment strategies - Current challenges \& future prospects. IJMR. 2018 : 148(6). 671-674. doi: 10.4103/0971-5916.252150

2. Techasrivichien, T., Darawuttimaprakorn, N., Punpuing, S. et al. Changes in Sexual Behavior and Attitudes Across Generations and Gender Among a Population-Based Probability Sample From an Urbanizing Province in Thailand. Arch Sex Behav 45, 367-382 (2016). https://doi.org/10.1007/s10508-014-0429-5

3. Angelina Mao and Ahalya Raguram. Online infidelity: The new challenge to marriages. Indian J Psychiatry. 2009 Oct-Dec; 51(4): 302-304. doi: 10.4103/0019-5545.58299

4. Vissers DC, Voeten HA, Nagelkerke NJ, Habbema JD, de Vlas SJ. The impact of pre-exposure prophylaxis (PrEP) on HIV epidemics in Africa and India: a simulation study.
PLoS One. 2008 May 7;3(5):e2077. doi:

10.1371/journal.pone.0002077.

5. Hoff CC, Chakravarty D, Bircher AE, Campbell CK, Grisham K, et al. Attitudes Towards PrEP and Anticipated Condom Use Among Concordant HIV-Negative and HIVDiscordant Male Couples. AIDS Patient Care STDS. 2015 Jul;29(7):408-17. doi: 10.1089/apc.2014.0315.

6. Blumenthal, J., \& Haubrich, R. (2013). Pre-exposure prophylaxis for HIV infection: how antiretroviral pharmacology helps to monitor and improve adherence. Expert opinion on pharmacotherapy. 2013. 14(13). 17771785. doi:10.1517/14656566.2013.812072

7. Grant RM, Lama JR, Anderson PL, McMahan V, Liu AY, Vargas L, et al. Preexposure chemoprophylaxis for HIV prevention in men who have sex with men. N Engl J Med. 2010 Dec 30;363(27):2587-99. doi: 10.1056/NEJMoa1011205.

8. Smriti Naswa, Y. S. Marfatia. Pre-exposure prophylaxis of HIV. Indian J Sex Transm Dis AIDS. 2011 Jan-Jun; 32(1): 1-8. doi:10.4103/2589-0557.81246

9. Golub SA, Gamarel KE, Rendina HJ, Surace A, LelutiuWeinberger CL. From efficacy to effectiveness: facilitators and barriers to PrEP acceptability and motivations for adherence among MSM and transgender women in New York City. AIDS Patient Care STDS. 2013 Apr.27(4):24854. doi: 10.1089/apc.2012.0419.

10. Saberi P, Gamarel KE, Neilands TB, Comfort M, Sheon N, Darbes LA, et al. Ambiguity, ambivalence, and apprehensions of taking HIV-1 pre-exposure prophylaxis among male couples in San Francisco: a mixed methods study. PLoS One. 2012;7(11):e50061. doi: 10.1371/journal.pone.0050061.

11. Brooks RA, Landovitz RJ, Kaplan RL, Lieber E, Lee SJ, Barkley TW. Sexual risk behaviors and acceptability of HIV pre-exposure prophylaxis among HIV-negative gay and bisexual men in serodiscordant relationships: a mixed methods study. AIDS Patient Care STDS. 2012

Feb;26(2):87-94. doi: 10.1089/apc.2011.0283

This work is licensed under a Creative Commons Attribution 4.0 United States License.

This journal is published by the University Library System of the University of Pittsburgh as part of its D-Scribe Digital Publishing Program and is cosponsored by the University of Pittsburgh Press.

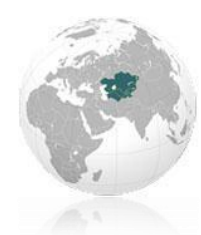


12. World Health Organization. People most at risk of HIV are not getting the health services they need. World Health Organization.

http://www.who.int/mediacentre/news/releases/2014/keypopulations-to-hiv/en/. Published July 11, 2014. Accessed April 8, 2020.

13. PrEP in Europe. The PrEP situation in Europe, European PrEP: a history. http://www.prepineurope.org/en/who-is-the-prep-ineurope-initiative/the-prep-situation-in-europe/. Accessed April 8, 2020

14. Bhattacharya J. HIV prevention \& treatment strategies - Current challenges \& future prospects. Indian J Med Res. 2018 Dec.148(6):671-674. doi: 10.4103/09715916.252150 .

15. Puneeta Vohra, Kahamnuk Jamatia, B Subhada, Rahul Vinay Chandra Tiwari, MS Nabeel Althaf and Chayan Jain. Correlation of CD4 counts with oral and systemic manifestations in HIV patients. J Family Med Prim Care. 2019 Oct; 8(10): 3247-3252. doi: 10.4103/jfmpc.jfmpc_767_19

16. World Health Organization. Consolidated guidelines on the use of antiretroviral drugs for treating and preventing HIV infection: Recommendations for a public health approach. $2^{\text {nd }}$ ed. Geneva: World Health Organization; 2016. https://www.who.int/hiv/pub/arv/arv-2016/en/. Accessed April 8, 2020

17. Kazemian, P., Costantini, S., Kumarasamy, N., Paltiel, AD., Mayer, KH., Chandhiok, N., Walensky, RP., Freedberg, KA. The Cost-effectiveness of Human Immunodeficiency Virus (HIV) Preexposure Prophylaxis and HIV Testing Strategies in High-risk Groups in India. Clin Infect Dis. 2020 Feb 3;70(4):633-642. doi: 10.1093/cid/ciz249.

18. UNAIDS . On the Fast-Track to end AIDS by 2030: Focus on location and population. UNAIDS, 2015, https://www.unaids.org/sites/default/files/media_asset/WA D2015_report_en_part01.pdf, Accessed April 8, 2020
19. Mayer KH, Chandhiok N, Thomas B. Antiretroviral pre-exposure prophylaxis: A new opportunity to slow HIV spread in India. Indian J Med Res. 2016 Feb; 143(2): 125128. doi: 10.4103/0971-5916.180194

20. PT Jyothi Datta. Cipla gets approval to sell its version of Truvada in India. Mumbai. The Hindu Business Line. https://www.thehindubusinessline.com/companies/ciplagets-approval-to-sell-its-version-of-truvada-inindia/article8637483.ece. Published May 23, 2016. Updated January 20, 2018. Accessed April 8, 2020

21. Seal DW, Benotsch EG, Green M, Snipes DJ, Bull SS, Cejka A, et al. The Use of the Internet to Meet Sexual Partners: A Comparison of Non-Heterosexually-Identified Men with Heterosexually-Identified Men and Women. Int J Sex Health. 2015; 27(1): 1-15. doi: $10.1080 / 19317611.2014 .918921$

22. Lutz C, Ranzini G. Where Dating Meets Data: Investigating Social and Institutional Privacy Concerns on Tinder. Social Media + Society. 2017. 3(1) 1-12. http://journals.sagepub.com/doi/10.1177/20563051176977 $\underline{35}$

23. Seal DW, Ehrhardt AA. Masculinity and urban men: Perceived scripts for courtship, romantic, and sexual interactions with women. Culture, Health, and Sexuality. 2003.5(4).295-319.

24. Rietmeijer CA, Bull SS, McFarlane M. Sex and the internet. AIDS. 2001 Jul 27;15(11):1433-4.

25. Georgia W, Wellman E. Tinder Is Big in India-at Least with Men. The Wall Street Journal; 2018 June 24. https://www.wsj.com/articles/india-has-lots-of-singlewomen-but-good-luck-finding-them-on-tinder1529869656. Published June 24, 2018. Accessed April 8, 2020

26. Deccan Chronicle. Grindr Lite comes to India, for users on slower phones, poor data network. Deccan Chronicle. Chennai. https://www.deccanchronicle.com/technology/inother-news/120320/grindr-lite-comes-to-india-for-users-

This work is licensed under a Creative Commons Attribution 4.0 United States License.

This journal is published by the University Library System of the University of Pittsburgh as part of its D-Scribe Digital Publishing Program and is cosponsored by the University of Pittsburgh Press.

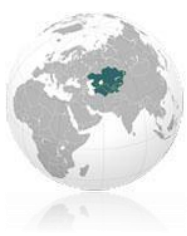


on-slower-phones-poor-data-netw.html. Published March 12, 2020. Accessed April 22, 2020.

27. McNeil Jr. DG. Grindr App to Offer H.I.V. Test Reminders. The New York Times. https://www.nytimes.com/2018/03/26/health/grindr-hivtest-reminder.html. Published March 26, 2018. Accessed April 8, 2020

28. Hornet User. This Pride Season, 'Undetectable = Untransmittable' Needs to Be Your Mantra. https://hornet.com/stories/undetectable-untransmittablepride. Published July 10, 2018. Accessed April 8, 2020

29. UNAIDS Explainer. Undetectable=Untransmittable Public Health and HIV Viral Load Suppression. Available from:

http://www.unaids.org/en/resources/presscentre/featurestor ies/2018/july/undetectable-untransmittable. Published July

20, 2018. Accessed April 8, 2020

30. Prof Alison J Rodger, FRCP Valentina Cambiano, PhD Tina Bruun, RN Prof Pietro Vernazza, MD Simon Collins Olaf Degen, MD et al. Risk of HIV transmission through condomless sex in serodifferent gay couples with the HIVpositive partner taking suppressive antiretroviral therapy (PARTNER): final results of a multicentre, prospective, observational study. The Lancet. 2019. 393(10189): 24282438. doi: 10.1016/S0140-6736(19)30418-0

31. Gayle D. New Facebook hook-up app shows which of your friends want to 'bang' you - (so long as you don't mind your other friends knowing too). Daily Mail; 2013 Jan 25. Available from:

http://www.dailymail.co.uk/sciencetech/article2268201/Facebook-hook-app-shows-friends-want-bangyou.html. Published January 25, 2013. Accessed April 8, 2020

32. Safronova V. Instagram Is Now a Dating Platform, Too. Here's How It Works. The New York Times. https:/www.nytimes.com/2017/12/21/style/instagramthirst-traps-dating-breakups.html. December 212017.

Accessed April 8, 2020
33. Arora K. India has the most FB users: Report. The Times of India; 2017 July 15.

https://timesofindia.indiatimes.com/india/india-has-themost-fb-users-report/articleshow/59603509.cms. Published July 15, 2017. Accessed April 8, 2020

34. Ivanski C, Kohut T. Exploring definitions of sex positivity through thematic analysis. The Canadian Journal of Human Sexuality. 2017 Dec; 26(3):216-225. DOI: 10.3138/cjhs.2017-0017

35. Garcia JR, Reiber C, Massey SG, Merriwether AM. Sexual Hookup Culture: A Review. Rev Gen Psychol. 2012 Jun 1; 16(2): 161-176. DOI: 10.1037/a0027911

36. Bhatta DN, Liabsuetraku T. Social self-value intervention for empowerment of HIV infected people using antiretroviral treatment: a randomized controlled trial. BMC Infect Dis. 2016; 16: 272. DOI: 10.1186/s12879-016-1634-8.

37. Mandelker DR. The Role of Law in Social Change. Osgoode Hall Law Journal. 1970 Nov; 8(2).

38. Abel RL. Law and Society: Project and Practice. Annual Review of Law and Social Science. 2010 Dec; 6:123. https://doi.org/10.1146/annurev-lawsocsci-102209$\underline{152851}$

39. Venkatesan J. Supreme Court recognises transgenders as third gender. The Hindu.

https://www.thehindu.com/news/national/supreme-courtrecognises-transgenders-as-thirdgender/article5914572.ece. Published April 15, 2014.

Accessed April 8, 2020

40. India Today. Section 377: Supreme Court's Right to Privacy judgment sparked fresh debate on decriminalising gay sex. India Today.

https://www.indiatoday.in/india/story/section-377supreme-court-right-to-privacy-judgment-sparked-freshdebate-on-decriminalising-gay-sex-1129699-2018-01-08. Published January 8, 2018. Accessed April 8, 2020 41. The Times of India. 'Gay sex is not a crime,' says Supreme Court in historic judgement. New Delhi: The

This work is licensed under a Creative Commons Attribution 4.0 United States License.

This journal is published by the University Library System of the University of Pittsburgh as part of its D-Scribe Digital Publishing Program and is cosponsored by the University of Pittsburgh Press. 
Times of India.

https://timesofindia.indiatimes.com/india/gay-sex-is-not-a-

crime-says-supreme-court-in-historic-

judgement/articleshow/65695172.cms. Published

September 6, 2018. Accessed April 8, 2020

42. Express Web Desk. SC hearing on Section 377

highlights: Law violates right to form association under

Article 19, say petitioners. The India Express.

https://indianexpress.com/article/india/supreme-court-

hearing-section-377-live-updates-decriminalisation-ofhomosexuality-5253008/. Published July 11, 2018.

Accessed April 8, 2020

43. The Hindu. 'Not a crime: on Supreme Court's adultery ruling'. The Hindu.

https://www.thehindu.com/opinion/editorial/not-a-

crime/article25061715.ece. Published September 28, 2018.

Accessed April 8, 2020

44. Sheth AN, Rolle CP, Gandhi M. HIV pre-exposure

prophylaxis for women. J Virus Erad. 2016 Jul; 2(3): 149-

155.

45. Goparaju L, Experton LS, Praschan NC et al. Women want Pre-Exposure Prophylaxis but are Advised Against it by Their HIV-positive Counterparts. J AIDS Clin Res.

2015 November; 6(11): 1-10. doi:10.4172/2155-

6113.1000522 .
46. Rodriguez-Jimenez J. Op-ed: It Is Time to End BottomShaming. The Advocate. https://www.advocate.com/31days-prep/2014/10/31/op-ed-it-time-end-bottom-shaming.

Published October 31, 2014. Accessed April 8, 2020

47. Centers for Disease Control and Prevention. Anal Sex and HIV Risk. Centers for Disease Control and Prevention. https://www.cdc.gov/hiv/risk/analsex.html. Published

October 27, 2016. Accessed April 8, 2020

48. Moskowitz, DA., Rieger, G, Roloff, ME. Tops, bottoms and versatiles. Sexual and Relationship Therapy; 2008; 23(3): 191-202.

49. Curry T. How PrEP Empowers Bottoms. The Advocate. https://www.advocate.com/hivaids/2015/9/25/how-prep-empowers-bottoms. Published September 25, 2015. Accessed April 8, 2020

50. Avert. Transgender people, HIV and AIDS. Avert. https://www.avert.org/professionals/hiv-social-issues/keyaffected-populations/transgender Updated: October 10, 2019. Accessed on: April 22, 2020.

51. Sevelius JM, Deutsch MB, Grant. R. The future of PrEP among transgender women: the critical role of gender affirmation in research and clinical practices. J Int AIDS Soc. 2016; 19(7Suppl 6): 21105. doi:

10.7448/IAS.19.7.21105

This work is licensed under a Creative Commons Attribution 4.0 United States License.

This journal is published by the University Library System of the University of Pittsburgh as part of its D-Scribe Digital Publishing Program and is cosponsored by the University of Pittsburgh Press. 